Access to Justice in Eastern Europe,

Issue 4 (8) 2020

ISSN 2663-0575 (Print)

ISSN 2663-0583 (Online)

http://ajee-journal.com

10.33327/AJEE-18-3.4

I Basysta, I Shepitko, O Shutova

'Protection and Risks of Illegal

Divulgation of Banking Secrecy in

Ukrainian Criminal Proceeding'

(2020) 4(8) Access

to Justice in Eastern Europe 298-305

10.33327/AJEE-18-3.4-n000042

\title{
PROTECTION AND RISKS OF ILLEGAL DIVULGATION OF BANKING SECRECY IN UKRAINIAN CRIMINAL PROCEEDING*
}

\author{
Basysta Iryna \\ Dr. Sc. (Law), Prof. of Criminal Procedure Department, \\ Lviv State University of Internal Affairs \\ Lviv, Ukraine \\ Shepitko Iryna \\ Ph. D. (Law), Senior Lecturer of National Security \\ and Legal Work Department, \\ Military and Legal Institute, Yaroslav Mudryi National \\ Law University \\ Kharkiv, Ukraine \\ Shutova Olga \\ Ph. D. (Law), Assist. Prof. of State Building Department, \\ Yaroslav Mudryi National Law University \\ Kharkiv, Ukraine
}

Summary: 1. Introduction. - 2. Guarantees of Banking Secrecy and Importance of its Nondisclosure. - 3. Procedure of Banking Secrecy Disclosure and Risks of its Illegal

Received: 18.09.2020. First revised: 03.10.2020. Second revised: 01.11.2020. Approved: 24.11.2020.

(C) 2020 Access to Justice in Eastern Europe, Basysta Iryna, Shepitko Iryna and Shutova Olga.

This work is licensed under a CC BY-NC 4.0 license.

This license allows reusers to distribute, remix, adapt, and build upon the material in any medium or

format for noncommercial purposes only, and only so long as attribution is given to the creator. 
Divulgation. - 4. Limits of Legal Divulgation in Criminal Proceedings. - 5. Concluding Remarks.

The author contributes to the national reform discussion to improve Ukrainian society's banking system confidence, approaching the European standards of financial services. Public confidence in banks focuses on performance, necessary for financial institutions, but negative feedback from the media, relatives, acquaintances regarding banks has bred significant mistrust. Among the root causes of an unflattering bank, image engenders the financial institution's inability to ensure customer information confidentiality regarding the banking secrecy. This article reviews the protection and illegal disclosure risks of banking secrecy, access to it within criminal proceedings, legal uncertainty of the Laws of Ukraine 'On Banks and Banking' and 'On Currency and Foreign Exchange Transactions', and proposed elimination method. Also provided are particular risks and recommendations for dealing with bank secrecy's apparent risks to continue improving adequate bank secrecy disclosure compliance with the FATCA Agreement.

Keywords: banking secrecy, banking secrecy protection, divulgation of banking secrecy, criminal proceedings.

\section{INTRODUCTION}

A challenge for the National Bank of Ukraine and other banks, including branches of foreign banks, established and operating in Ukraine following Ukrainian laws, comprehensively strengthen Ukrainian societal confidence in the Ukrainian banking system. While in 2015 , only $19 \%^{1}$ of Ukrainians did not trust banks, in 2017, this index rose to $53 \%$.

According to the first quarter of 2018, the Austrian Raiffeisen Bank Aval, the French UKRSIBBANK, and the American City Bank became the banks' Mind viability rating, an information project assessing large Ukrainian financial institutional reliability. The Dutch ING Bank Ukraine and the Swedish SEB Corporate Bank followed. ${ }^{2}$

In April 2019, the National Bank of Ukraine stated public confidence in the Ukrainian central bank and other public authorities remained low, although some noticed positive trends. ${ }^{3}$ During the year, Ukrainians increased the volume of UAH deposits in banks by $15 \%$, as the head of the National Bank of Ukraine, Yakiv Smolii, articulated in his speech in the Verkhovna Rada. ${ }^{4}$

1 'The level of confidence of Ukrainians in banks last year fell almost three times' (Mind.ua, 7 June 2018) $<$ https://mind.ua/news/20185603-riven-doviri-ukrayinciv-do-bankiv-minulogo-roku-vpav-majzhevtrichi> accessed 18 September 2020.

2 O Zaruba, O Butenko, Ye Shpytko, R Kornyliuk, 'Rating of banks: the state of financial institutions in the first quarter of 2018' (Mind.ua, 16 May 2018) <https://mind.ua/publications/20184781-rejtingbankiv-yak-pochuvalisya-finustanovi-v-i-kvartali-2018-roku> accessed 18 September 2020.

3 'The level of public confidence in the banking system of Ukraine remains low' (Espreso.tv, 9 April 2019) <https://espreso.tv/news/2019/04/09/riven_doviry_do_bankiv_v_ukrayini_zalyshayetsya_nyzkym_ nbu> accessed 18 September 2020. ; Official Facebook page of the National Bank of Ukraine <https:// www.facebook.com/NationalBankOfUkraine/photos/a.1505513382996162/2261146620766164/?type= 3\&theater> accessed 18 September 2020.

4 'Trust in banks increases among Ukrainians: amount of deposits raised by 15\% during the year - NBU' (TSN.UA, 17 January 2019) <https://tsn.ua/groshi/v-ukrayinciv-zrostaye-dovira-do-bankiv-za-rikobsyag-depozitiv-zris-na-15-nbu-1282206.html > accessed 18 September 2020. 
Public confidence in banks resides not only on performance, necessary for financial institutions, but also the trust of bank relatives, friends, and acquaintances. A study of consumer Ukrainian financial service awareness about the deposit guarantee system indicated 49\% of respondents from the working group of the Expert Council of the Deposit Guarantee Fund identified the factors they pay attention to when choosing a bank. ${ }^{5}$ The communication channels Ukrainians trust the most, in terms of financial services, entailed television, the Internet, friends and family.

These constituents reflect the generalised citizen bank perceptions and confidence in the banking system the institutional ability to maintain banking secrecy. However, the available Internet posts and media reports partly call into question some banks' ability. Ulteriorly, information interpreted among ordinary citizens disseminates, fostering distrust. Notably, many Ukrainian personal data posts include those related to property status, often falling into fraudulent hands, and one leakage source constitutes banks collecting clients' data. The state only legally guarantees bank secrecy preservation. However, is it reliably protected?

The other side of the problem relates to the fact the Law of Ukraine 'On Ratification of the Agreement between the Ukrainian and United States of American Governments to improve tax compliance and applies US Foreign Account Tax Compliance Act (FATCA),

according to the official web portal of the Verkhovna Rada of Ukraine, was returned on 4 November 2019 with the signature of the President. ${ }^{6}$ Both economists and lawyers ambiguously perceived this, in particular, eloquent headlines of publications, both in economic and legal columns, such as 'A step towards the abolition of bank secrecy.?

This assertion makes it urgent and appropriate to outline the issue related to such subjects to protect bank secrecy from illegal disclosure risks (divulgation), criminal proceedings access, distinguishing those to be urgently addressed, and propose appropriate road maps to offset adverse impacts. This action will generally raise confidence in the Ukrainian banking system to a respectable level.

The publication aims to study the banking secrecy protection and risks of illegal disclosure (divulgation), criminal proceedings access, identify specific problems of such activities, gaps and conflicts in legislation, eliminating and subsequently strengthen Ukrainian banking confidence.

\section{BANKING SECRECY GUARANTEES AND NONDISCLOSURE IMPORTANCE}

Art. 61 of the Law of Ukraine On Banks and Banking Activity obliges Ukrainian banks to maintain banking secrecy. The same article provides mechanisms for maintaining

5 https://www.fg.gov.ua/storage/editor/files/dgf-survey-18may2020-ua-covers_1594302558.pdf

6 Draft Law of Ukraine 'On Ratification of the Agreement between the Government of Ukraine and the Government of the United States of America to Improve the Implementation of Tax Rules and the Application of the Provisions of the US Law on Foreign Account Tax Compliance Act (FATCA) [2019] Official web-portal of the Verkhovna Rada of Ukraine <https://w1.c1.rada.gov.ua/pls/zweb2/ webproc4_1?pf3511=66759> accessed 18 September 2020.

7 O Makeieva, 'A step towards the abolition of bank secrecy. What will change' (NV Business, 11 November 2019) <https: //nv.ua/ukr/biz/experts/ugoda-fatca-shcho-v-niy-ukrajina-za-krok-do-skasuvannyabankivskoji-tayemnici-50052685.html> accessed 18 September 2020. 
banking secrecy, which at first seems appropriate. Banks should guarantee each client's data revealed to the bank during servicing transactions, including private or third parties relationships, will not be disclosed and used to benefit bank employees. ${ }^{8}$

Thus, according to the Law, bank employees must sign a commitment to banking secrecy upon taking office. Moreover, contracts and agreements between the bank and the client must stipulate banking secrecy and accountability for its disclosure. Furthermore, banks must limit the number of persons who have access to confidential data, provide special record-keeping sensitive documents, and technically prevent unauthorized access to electronic and other media.

Banking secrecy non-disclosure is presented both in departmental regulations, emphasized in the Law of Ukraine № 3163-IV of 1 December 2005 and legislatively. The National Bank of Ukraine holds top place, legislating storage, protection, use, and disclosure of banking secrecy data and an interpreting rule application. Banks commonly disclose sensitive information, illegally collected or used. The latest innovations introduced in banking secrecy entail the Law of Ukraine № 2473-VIII of 21 June $2018^{9}$. As a result, the third part of Art. 60 of the Law of Ukraine 'On Banks and Banking' was amended to protect client financial information, collected during banking and currency supervision, and designated to banking secrecy. ${ }^{10}$

These two Laws' wording differs slightly due to different conjunctions the legislator used, in particular, in Art. 60 of the Law of Ukraine On Banks and Banking in the phrase 'information about banks or clients' ${ }^{\text {'11 }}$ the conjunction 'or' is used and in the Law of Ukraine № 2473-VIII of 21 June 2018 'On Currency and Currency Transactions' they use the conjunction 'and (or). ${ }^{12}$ As far as we are concerned, the law enforcement practice may encounter several challenges under the circumstances. After all, the conjunction 'or' can be interpreted by some lawyers like the one that is used when combining homogeneous members of a sentence and parts of a complex sentence to indicate that of some listed objects, and phenomena only one is possible, and others - as the one used in the meaning of the connecting conjunction 'and.' ${ }^{13}$

In both cases, the parties will be right. Given this duplicity, the legislator should avoid such legal uncertainty.

The Criminal Code of Ukraine (CC) establishes liability for these illegal acts in Art. 231 of the Law of Ukraine- for intentional actions aimed at obtaining data constituting banking secrecy (illegal collection), for disclosure or other data use, and illegal data use, if it has caused significant harm to the business entity. In turn, CC Article 232

8 The Law of Ukraine 'On Banks and Banking' [2001] Vidomosti of the Verkhovna Rada 5-6/ 30 (last updated on 17 October 2019) <https://zakon.rada.gov.ua/laws/show/2121-14> accessed 18 September 2020.

9 Law (n 10).

10 The Law of Ukraine 'On Currency and Currency Transactions' [2018] 30/229 <https://zakon.rada.gov. ua/laws/show/2473-19> accessed 18 September 2020.

11 Law (n 7).

12 Law (n 10).

13 'Dictionary of the Ukrainian language. Academic Explanatory Dictionary (1970-1980)' <http://sum. in.ua/s/chy> accessed 18 September 2020. 
holds those intentionally disclosing banking secrecy without owner consent and aware banking secrecy in connection with professional or official activities accountable if they committed such an illegal act for selfish or other personal reasons and caused significant harm to the business. ${ }^{14}$ Empirical data has indicated the number of convictions for this offence remains negligible. However, this does not mean such criminal transgressions are not committed. Researchers emphasising criminal activity prevention and cessation in banking (financial) services cannot ensure criminal law enforcement, illuminating the need for a comprehensive approach. ${ }^{15}$

Scrutinising the Unified State Register of Court Decisions has established only three criminal proceedings under CC Art. 231 of which no convictions resulted. According to the search details of the qualification under CC Article 232 placed in this Register, the three convictions did not entail commercial or banking secrecy disclosure. ${ }^{16}$

In most countries, the disclosure of bank or trade secrets is associated with industrial espionage, considered a crime in Austria, Belgium, Bulgaria, Denmark, Lithuania, Germany, the United States, and Switzerland. This act investigates people's trade secrets and the person to whom they were entrusted disclosing the secrets. ${ }^{17}$ Creating visible legitimacy of obtaining and disclosing secrets should be added to this list of acts. Unfortunately, such activities may include the commencement of criminal proceedings, in such a procedure will facilitate the disclosure of bank or trade secrets.

\section{PROCEDURE OF BANKING SECRECY DISCLOSURE AND RISKS OF ITS ILLEGAL DIVULGATION}

Art. 62 of the Law of Ukraine 'On Banks and Banking Activity' regulates the procedure for disclosing information to legal entities and individuals containing banking secrecy. This norm details the general procedure and the grounds, conditions, and banking secrecy disclosure subjects. The same article highlights the persons guilty of violating banking secrecy disclosure and use remain liable under the laws of Ukraine..$^{18}$ Consequently, the eloquent titles of publications such as 'A Step Towards the Abolition of Banking Secrecy'19 seem somewhat dissonant, as it has already been realised. As follows from her text analysis, the author of that post professionally dealt with all issues related to the FATCA Agreement signing in Ukraine. The author's predictions about the next legislative steps were compelling. Explicitly, the FATCA Agreement would only work in Ukraine when the relevant amendments to the current Ukraine legislation have been

14 Criminal Code of Ukraine, edition of 18 October $2019<$ https://zakon.rada.gov.ua/laws/show/2341-14> accessed 18 September 2020.

15 VYu Shepitko, MV Shepitko, BV Shchur, MO Voloshyna, 'Bankivska diialnist v Ukraini: Negatyvni vyklyky suchasnosti I zlochynni vplyvy' ['Banking in Ukraine: negative challenges of modernity and criminal influence'] (2019) 2 (29) Financial and credit activities: problems of theory and practice 86 $<$ fkd.org.ua/article/download/ 171937/173377> accessed 18 September 2020.

16 Unified state register of court decisions $<$ http://reyestr.court.gov.ua $>$ accessed 18 September 2020.

17 VN Dodonov, OS Kapinus, SP Shcherba, Comparative criminal law. Special part: monograph (Yurlitinform 2010).

18 Law (n 7).

19 Makeieva (n 6). 
made. In the short run, the Verkhovna Rada of Ukraine considered the relevant draft laws developed to implement the FATCA Agreement, namely Bills 2102 and 2103. Draft Law 2102 supplementing Art. 62 Procedure for Disclosure of Banking Secrecy of the Law of Ukraine On Banks and Banking. ${ }^{20}$

Thus, it should be noted the author of the analyzed article, declaring its 'conflicting' title, correctly perceives all the innovations and gives a thorough prediction of further legislative steps to be taken. At the same time, it would be more logical to link the declarative names with changes and additions to the procedure for disclosure of information on legal entities and individuals, which contains banking secrecy, rather than with 'abolition of banking secrecy, which, in our view, is unacceptable in a democratic and legal society. The objective of the specified FATCA Agreement, in the first instance, does not consist in abolishing banking secrecy, but, as stated on the official web portal of the Verkhovna Rada of Ukraine,

... to improve the implementation of tax rules. The agreement aims to increase compliance with international tax law and ensure the application of the FATCA Law provisions through internal reporting and automatic information exchange. ${ }^{21}$

Along with the legal guarantees for preserving banking secrecy, the standardized procedure for disclosing data on legal entities and individuals containing banking secrecy. Risks of illegal disclosure (divulgation) of banking secrecy still exist.

Among disclosure risks and the conditions contributing to this, researchers have identified an illegal market where such information is bought and sold. A potential source of personal data leakage involves photocopying various citizens' documents, which many organizations perform. Also, the primary risks associated with banks in liquidation (when transferring documents surface during liquidation from current managers to temporary administrators, many bottlenecks occur when financial institutions weaken internal security, control over compliance with data protection. When the interim administration is operational, the bank no longer has the technical, financial, or human resources to protect the respective information fully. ${ }^{22}$

Access to banking secrecy in criminal proceedings frequently occurs when investigating the so-called economic criminal offences. For example, in the pre-trial investigation, the investigator can access sensitive documents when performing criminal proceedings (Art. 159-166 of the Criminal Procedure Code of Ukraine (CPC). Hence, the legislator has classified information, contained items and documents, and constitutes a bank secret and protected by law (CPC paragraph 5 of part 1 of Art. 162). The investigating judge determines temporary access to articles, data, and material (CPC part 2 of Art. 159), for which the parties to the criminal proceedings have the right to apply to the investigating

$20 \quad$ Makeieva (n 6).

21 The Law on Ratification of the Agreement between the Government of Ukraine and the Government of the United States of America was adopted to improve the implementation of tax rules and the application of the provisions of the US Law on Foreign Account Tax Compliance Act (FATCA). Official web-portal of the Verkhovna Rada of Ukraine <https://www.rada.gov.ua/news/Novyny/183499.html> accessed 18 September 2020.

22 V Avdieienko, 'Banking secrecy in Ukraine: why things are not going so well' <https://politerno.com.ua/ papers/bankivska-tayemnytsya-v-ukrayini-chomu-vse-duzhe-pogano/> accessed 18 September 2020. 
judge during the pre-trial investigation or trial during the proceedings (CPC part 1 of Art. 160). In the case of a request for access to an article, item, or material, containing a secret protected by law, the subjects submitting it should indicate data use as evidence and illustrate the data cannot be secured by another means (CPC paragraph 6 of part 2 of Article 160). According to CPC part five of Art. 163, the investigating judge or court shall grant temporary access if the party to the criminal proceedings meets these criteria. ${ }^{23}$

\section{LEGAL DIVULGATION LIMITS OF BANKING SECRECY IN CRIMINAL PROCEEDINGS}

The investigated criminal proceedings in which access to banking secrecy was provided can be reduced to the following example. On 13 August 2012, the Zdolbuniv District Prosecutor's Office's senior investigator asked the court to enable the Bank to disclose the LLC's banking secrecy and seize documents containing banking secrecy. The investigator substantiated the request by the fact the Zdolbuniv District Prosecutor's Office was investigating criminal proceedings against the Chief State Tax Auditor of the Inspector of the Department of Control and Verification of the Department of Taxation of Individuals of the State Tax Inspectorate in Rivne on the grounds of abuse of office and forgery under CC Article 364, paragraph 3, Art. 366, paragraph 2. During the pre-trial investigation, it became necessary for the Bank to disclose banking secrecy and seize the LLC documents containing banking secrecy. To verify the facts of LLC financial and economic transactions with the private entrepreneur Peter Sidorovskyi, they had to examine the cash flow of Peter Sidorovskyi for the period from 1 January 2008 to the present to determine the number of payments, their type, designation and the date of their transfer to the counterparty. At the court hearing, the prosecutor and the investigator supported the request. After assessing the request, the criminal proceedings' materials, and hearing the investigator and the prosecutor's opinion, the court considered the request was subject to satisfaction. As a result, the court decided to allow the Bank to disclose client banking secrecy- the LLC, regarding deposits and cash flows in personal accounts, and to seize from official client bank documents- the LLC: cases on the legal account implementation, including cards with samples of signatures and the enterprise seal, the bank cash flow statement in connection to these accounts indicating the transaction date, the name, and the counterparty code, the amount and purpose of payment in originals and in full for the period from the moment of account opening to the day of the order. ${ }^{24}$

According to the $\mathrm{CPC}$, the subjects of a petition for temporary access to an article, thing, or material containing a secret protected by law are obliged to indicate the item's use as evidence and the impossibility otherwise obtaining it. This issue is not considered in the given an example, and its solution lies within the evaluation (hypothetical) limits. Thus, the law encourages access to banking secrecy items only as a last resort, but the list of such cases is not provided, leaving justice to the judge's discretion. A legal gap can lead to bank secrecy violations. This may be particularly the case in situations where a pre-

23 Criminal Code of Ukraine (n 14).

24 Unified register (n 16). 
trial investigation in which banking secrecy led to the conclusion no crime transpired. In this case, the violation of the banking institution's everyday activities, banking secrecy disclosure, posed no urgent need.

\section{CONCLUDING REMARKS}

Banking secrecy protection, provided both by the Law of Ukraine On Banks and Banking and other Ukrainian laws and departmental regulations, remain appropriate. However, the declared system of guarantees of banking secrecy non-disclosure is not exhaustive and sufficiently effective.

Hence, for better implementing the FATCA Agreement, it is expected:

- eliminate existing illegal disclosure risks (divulgation) of banking secrecy, regulate documents circulation and preservation containing banking secrecy, including during liquidation proceedings; take a more careful approach to staff selection and responsibilities;

- agree on the wording of Art. 60 of the Law of Ukraine On Banks and Banking and the provisions of the Law of Ukraine On Currency and Currency Transactions by using the same conjunction and state the phrase in both laws in the following wording: 'information on banks and (or) clients';

- list emergency cases in Art. 160, 163 of the CPC of Ukraine, when banking secrecy may be disclosed. 